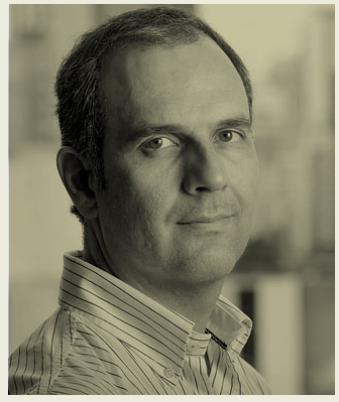

\title{
FINANÇAS: O CALCANHAR DE AQUILES DOS EMPREENDEDORES
}

Mesmo que não tenham formação específica em administração, os empreendedores geralmente entendem (ou pensam que entendem) um pouco de recursos humanos, marketing, estratégia ou operações. O que parece mesmo ser a pedra no sapato de quem está à frente de um negócio são as finanças.

Por não compreenderem ou não gostarem dessa área, muitos delegam as atividades financeiras a alguém sem formação ou experiência, o que pode prejudicar a empresa. Quando o empreendedor tenta tomar pé da situação, o estrago já está feito e, frequentemente, o resultado é a falência.

Assim, seguem algumas dicas para quem está pensando em empreender, mas não tem muita familiaridade com finanças:

1. Escolha um sócio que entenda do assunto. Se você for uma pessoa orientada para vendas, de nada adianta seu sócio também ser dessa área. É preferível levar em conta a complementariedade das habilidades e das experiências, embora seja fundamental que os sócios partilhem os mesmos valores morais e éticos;

2. Muito cuidado na definição do escritório de contabilidade que vai prover os serviços para a sua empresa. Procure referências, fale com outros clientes, faça um levantamento para saber se não há processos. Enfim, como toda área, há bons e maus profissionais. Dada a importância envolvida, invista tempo nessa escolha;

3. Mesmo que você não goste de finanças, procure sempre se inteirar da situação, conferir os extratos bancários, dar uma olhada nas contas. Isso poderá evitar surpresas desagradáveis no futuro;

4. Atenção redobrada com o fluxo de caixa, que, de forma simplificada, pode ser entendido como quanto a empresa tem no banco ao fim de cada dia. Um negócio pode até obter lucro no fim do ano, mas se não houver um acompanhamento minucioso desse item, pode falir no meio do caminho;

5. Evite pegar dinheiro no banco para cobrir seu fluxo de caixa. Você vai pagar juros altíssimos. O melhor é negociar prazo de pagamento com seus fornecedores e clientes. Se a empresa tiver bens como automóveis ou imóveis, uma opção é vendê-los e utilizar leasing ou pagar aluguel - as taxas são bem menores do que as do financiamento bancário;

6. Por incrível que possa parecer, poucos empreendedores sabem o custo real de seus produtos. Ter um sistema de custeio eficiente, que permita conhecer o custo efetivo de cada produto, auxilia na precificação e no consequente cálculo da margem de lucro;

7. Nunca misture as finanças pessoais com as do negócio. Afinal, o que é da empresa é da empresa. Não utilize o dinheiro do caixa para pagar as contas da sua casa ou o seu almoço. Estabeleça um pró-labore que satisfaça suas necessidades básicas.

Se o empreendedor se atentar a esses pontos, vai aumentar muito as chances de sobrevivência da sua empresa. Quem sabe até não comece a gostar da área, fazer cursos e utilizar ferramentas financeiras mais sofisticadas? 